DOI 10.18551/rjoas.2019-06.24

\title{
A STUDY OF CARRYING CAPACITY OF WATER RESOURCES FOR THE DEVELOPMENT OF ECO-FRIENDLY SHRIMP FARMING IN MALAKA REGENCY, WEST TIMOR OF INDONESIA
}

\author{
Liufeto Franchy Ch. \\ Doctoral Program of Fisheries and Marine Science, Faculty of Fisheries and \\ Marine Science, University of Brawijaya, Malang \& Faculty of Fisheries and Marine Science, \\ University of Nusa Cendana, Indonesia
}

\author{
Soemarno \\ Faculty of Agriculture, University of Brawijaya, Malang, Indonesia
}

Ekawati Arning Wilujeng

Faculty of Fisheries and Marine Science, University of Brawijaya, Malang, Indonesia,

Harahab Nuddin*

Faculty of Fisheries and Marine Science, University of Brawijaya, Malang, Indonesia

*E-mail: marmunnuddin@ub.ac.id

\begin{abstract}
This research explores the opportunities for developing eco-friendly shrimp farming. It aims to examine the environmental carrying capacity of nearshore water for shrimp farming. Quantitative estimation method was employed to assess the carrying capacity of an environment based on the total volume of seawater and the capacity of available oxygen dissolved in the water. The research result shows that the development potential of shrimp farming in Malaka Regency is fairly great, based on the total volume of available seawater in coastal Wewiku, reaching up to $213,473,289.8 \mathrm{~m} 3 /$ day, while the availability of dissolved oxygen to dilute organic waste reaches $327,140.89 \mathrm{~kg} \mathrm{O}_{2} /$ day. Then the daily capacity of organic waste reaches $1,635,704.43 \mathrm{~kg}$. Based on the carrying capacity of the Wewiku waters to contain organic waste, intensive developments of shrimp farming are possible for an area of 177 ha, with 3,240.03 tons/MT of production. If the land is developed up to 685.12 ha, shrimp production can be increased up to $4,028.52$ tons/MT. For semi-intensive and traditional plus shrimp farming options, the area developed can be expanded up to $1,415.84$ ha and 3,352.54 ha with shrimp production capacity of 4,516.54 tons/MT and 2,581.46 tons/MT respectively for each area.
\end{abstract}

\section{KEY WORDS}

Carrying capacity, shrimp culture, opportunity, environmentally friendly production.

In addition to milk fish, shrimp is one of the fishery potentials in Wewiku District, Malaka Regency. Various studies and information from Liufeto [1], BPP [2], ATSEF [3], Motaain Fish Quarantine Border Post, BKIPM Kupang 2010-2014, advise that there has been a decrease in the supply of shrimp caught from Malaka, including black tiger shrimp (Penaues monodon) and white shrimp (Pena marguiensis), resulting in the declining caught shrimp volumes traded to Java, Bali and Timor Leste, that even traders have failed to meet market demand in certain seasons.

Data by Belu and Malaka Central Bureau of Statistics (BPS) of 2008-2013 [5] suggests that the total production of white shrimp and black tiger shrimp did actually decline, from 84.3 tons in 2008 to 34.9 tons in 2010 . Even the volume of white shrimp and tiger shrimp in the waters was considerably stagnant throughout 2011 to 2013, with an average production rate of 45.8 tons and 5.2 tons/year. This condition indicates the great potential of shrimp farming, in addition to strategic implementation of the concept of sustainable caught shrimp 
management. Belton and Thilsted [6] state that there has been a fundamental transition in the fishery sector, as players have shifted from fishing-based to farming-based supply.

FAO [7] shows that in 2018 , half of fish consumption was obtained from cultivation. In the global era, aquaculture activities have become a reliable source of meeting world seafood needs [8-12].

According to Leung et al., [13] and Anderson [14], the key economic aspects in selecting commodities for aquaculture development include having strong potential market demand and high selling prices in both domestic and export markets, having strong potential to be produced at a reasonable cost, and having strong potential for value added products. However, Widigdo [15] notifies that maximizing short-term economic benefits without considering ecological support will only lead to environmental degradation and ecological crisis.

The development of shrimp farming is generally executed on an intensive farming scale, while organic waste, including fish food waste, feces and other dissolved materials, on an intensive scale is proven to have an impact and to pose risks of damage to the environment $[16,17,18]$. Therefore, the development of eco-friendly shrimp farming ponds must consider these two important aspects, including the quantification of farming waste and the ability of nearshore waters to contain farming waste [19].

One of the methods to estimate the carrying capacity of water resources developed to measure the ability of the waters to contain farming waste is to evaluate the available capacity of dissolved oxygen in the waters to decompose organic waste from aquaculture activities. This is conducted by predicting the volume of waste that can be accommodated by nearshore waters based on the availability of dissolved oxygen in the water column when tidal changes in the waters [20,21].

This study of the carrying capacity of water resources is important for the purpose of developing aquaculture activities for shrimp commodity in Malaka. Wewiku District is decided as the site of research by considering the $L Q$ value indicator of $>1$, indicating the region is considered more productive in fulfilling farming production demand of the surrounding area and export demand. Thus, the study aims to examine the carrying capacity of the water resources of the Wewiku District with regard to potential application of eco-friendly shrimp farming in Malaka Regency.

\section{MATERIALS AND METHODS OF RESEARCH}

This research was conducted in 3 coastal villages located in the Wewiku District of Malaka Regency, focusing on 4 research stations known to be the centers of aquaculture activities in Wewiku District, including Baderai (B) station in Baderai village, Tuatolu station $(\mathrm{T})$ and Uluklubuk $(\mathrm{U})$ stations in Weoe village, and Weseben $(\mathrm{W})$ station in Weseben village. The distribution of farming ponds in Wewiku District is presented in Figure 1.

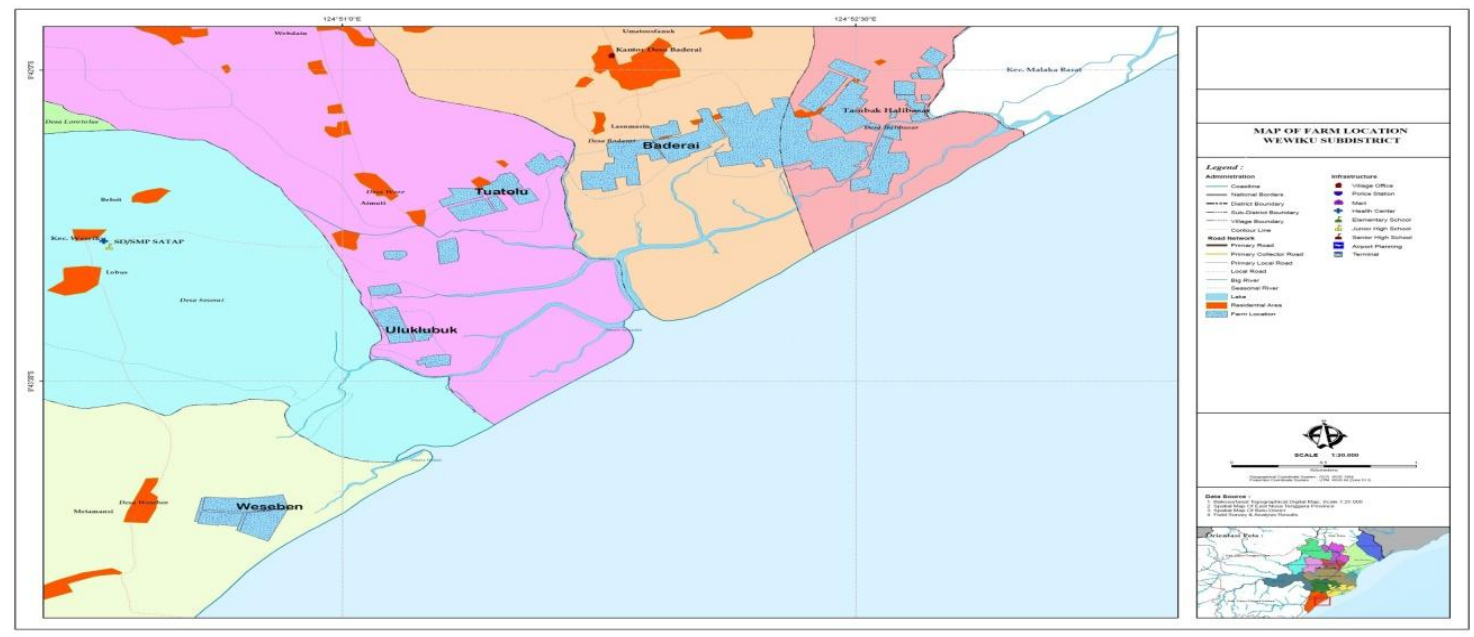

Figure 1 - Observation Station and Research Sampling 
Estimation of environmental carrying capacity of the coastal area of Wewiku District was conducted at 4 research stations considered representative to the ecological conditions and aquaculture activities in Wewiku District. Estimation of carrying capacity of water resources for eco-friendly land development and production of shrimp farming was conducted based on the evaluation of dissolved oxygen availability of the total volume of seawater entering nearshore waters at high tide. Calculation of total seawater volume was done by calculating the total volume of sea water entering nearshore waters at high tide, the volume of remaining water at low tide, and the volume of water available in one tidal cycle.

Tidal range value data (h) was obtained from measuring the low tide of Baderai beach for 15 days (15x24 hours), which was representative to the other 3 stations as the Baderai farming pond has been more productive than other regions, in addition to easier access to its coastal area. The measurement of the height of low tides was carried out using scaled bamboo.

The length of coastline $(\mathrm{y})$ was obtained from the data of distance coordinates based on the measurement result using Global Positioning Systems (GPS), indicating the position from Weseben beach to Baderai beach. To calculate the bedslope, the highest and lowest contour data, and water coordinates data verified by manual water depth measurements were collected, in addition to distance data of each contour coordinate, representing each research station. Data of distance from coastline to the sea at low tide at each station was obtained by using Global Positioning Systems (GPS).

According Boyd [22] explains that the tidal turnover would provide or supply oxygen in nearshore waters to decompose farming waste, thus the measurement of dissolved oxygen availability was carried out at high tide. Dissolved oxygen supply from the waters entering the 4 stations of the existing farming area was measured in the main channel of sea water, and observation was carried out for 15 days to get an estimation of the volume of dissolved oxygen at the time of high and low tides.

To find out the land area and shrimp production volume based on the carrying capacity of water resources, it is important to know the volume of waste from shrimp farming activities in ponds, and the capacity of waters to contain organic waste based on the calculation of the availability of dissolved oxygen entering the waters to dilute shrimp farming organic waste.

Because the activities of shrimp farming in the research site have never been done before, then the data on the volume of organic shrimp waste used in this study was secondary from the result of the study. Allaudin [23] reported that the volume of organic waste in the form of TSS produced in shrimp farming intensively with shrimp population density of $126 \mathrm{fish} / \mathrm{m} 2$ was approximately $9,228.52 \mathrm{~kg} / \mathrm{ha} / \mathrm{farming}$ season, while for a population density of shrimp of $50 \mathrm{fish} / \mathrm{m} 2$, the organic waste was approximately $2,387.46$ $\mathrm{kg} / \mathrm{ha} / \mathrm{farming}$ season. For semi-intensive systems with a population density of $25 \mathrm{fish} / \mathrm{m} 2$ and traditional plus with a population density of $8 \mathrm{fish} / \mathrm{m} 2$, the volume of organic waste produced was $1,155.29 \mathrm{~kg} / \mathrm{ha} /$ farming season and $487.90 \mathrm{~kg} / \mathrm{ha} /$ farming season.

The data used to calculate the capacity of the waters to contain organic waste was the primary one from the calculation of the total volume of sea water entering the waters and the availability of dissolved oxygen

The volume of seawater entering the nearshore waters at high tide (Vo) was calculated using the following formula by Widigdo and Pariwono [24]:

$$
\text { Vo }(m 3)=0.5 \cdot h \cdot y(2 x-h / \operatorname{tg} \Theta)
$$

Where: $V_{0}=$ volume of seawater entering the waters when tide is high (m3); $h=$ tidal range of the area; $y=$ coastline $(\mathrm{m}) ; \mathrm{x}=$ distance from coastline (high tide) to the farming pond; $\theta=$ slope of seabed.

While the volume of water remaining at low tide (Vs.) was determined by the formula:

$$
\text { Vs }(m 3)=0.5 \cdot h \cdot y[2 x-(2 h-1) / \operatorname{tg} \Theta]
$$


Thus, the volume of remaining water in nearshore waters (Vos) in one tidal cycle ( $f$ ) to dilute farming waste (joining equations 1 and 2) became:

$$
\operatorname{Vos}(\mathrm{m} 3)=0.5 \text {.h.y }[4 x-(3 h-1) / \operatorname{tg} \Theta]
$$

If the tidal frequency is $f$ times a day, then the total volume of water remaining in nearshore waters to dilute the waste is:

$$
\operatorname{Vtot}(m 3)=f . V 0 s
$$
formula:

Retention time calculation of water entering the waters was done using the following

$$
\mathrm{WT}=(\mathrm{Vo}+\mathrm{Vs}) / \mathrm{Vs}
$$

To calculate the carrying capacity of farming waste, it is necessary to know the flushing time of the waste to the waters. It was calculated using the following formula:

$$
\begin{aligned}
& F T=1 / D \\
& D=[V P t-V P s] / F . V P t
\end{aligned}
$$

Where: $\mathrm{FT}=$ Flushing Time (day); $\mathrm{D}=$ Dillution Rate; VPt $=$ Volume of nearshore waters at highest tide (m3); VPs = Volume of nearshore waters at lowest tide (m3); F = Tidal frequency in a day.

The results of research by Widigdo [15], Poernomo [25], Boyd [22], and Wedemeyer [26] conclude that the minimum level of dissolved oxygen for cultivated organisms is $3 \mathrm{mg} / \mathrm{l}$. If the dissolved oxygen availability in the water column (Oka) is X $\mathrm{mg} / \mathrm{l}$, then the availability of dissolved oxygen (Oak) which can support assimilation of waste in waters is:

$$
\text { Oak }(m g / l)=X m g-3 m g / l
$$

If the total volume of water remaining in nearshore waters (Vtot) and flushing time (day) are known, the available capacity of dissolved oxygen (Kot) in the water column per day is equal to:

$$
\text { Kot }=[\text { Vtot } / F T]: \text { Oak }
$$

According to the analysis by Willioghby referred in Meade [20], dissolved oxygen needed to decompose the load of organic waste entering and staying in nearshore waters is $0.2 \mathrm{~kg} \mathrm{O} 2 / \mathrm{kg}$ of organic waste. Thus the environmental carrying capacity (DDL) to contain a volume of organic waste is:

$$
\operatorname{DDL}(\mathrm{kg} / \text { day })=\text { Kot: } 0.2 \mathrm{~kg}
$$

If the volume of organic waste per $\mathrm{kg}$ of organism $=\mathrm{E}$, then the production capacity of shrimp farming is in accordance with the environmental carrying capacity:

$$
\mathrm{F}=\mathrm{D} / \mathrm{E}
$$

Where: $\mathrm{D}=$ the volume of organic waste contained in nearshore waters $(\mathrm{kg} / \mathrm{day}) ; \mathrm{F}=$ shrimp production volume fitting to the environmental carrying capacity $(\mathrm{kg})$. 


\section{RESULTS OF STUDY}

Recapitulation of data of sea tides measured, distance from coastline at high tide to the location of seawater collection, coastline length and slope of seabed, tidal height in Wewiku waters within 15 days of measurements reached an average of $1.23 \mathrm{~m}$ with tidal frequency 2 times a day. The detail results are presented in Table 1, with a tidal display shown in Figure 2.

Table 1 - The physical condition of the near-shore waters of Wewiku District

\begin{tabular}{lll}
\hline No & Parameter & Observation Result \\
\hline 1 & Coastline length of Wewiku District & $1,200 \mathrm{~m}$ \\
& a. Baderai Village & $1,400 \mathrm{~m}$ \\
& b. Weoe Village & $3,320 \mathrm{~m}$ \\
& C. Weseben Village & $5,920 \mathrm{~m}$ \\
& Total & 0.1771 \\
2 & Mean value of Wewiku nearshore bedslope $\left(^{\circ}\right)$ & \\
3 & Distance from coastline (high tide) to the farming pond: & $1,800 \mathrm{~m}$ \\
& a. Pond Baderai & $1,720 \mathrm{~m}$ \\
& b. Pond Tuatolu & $2,818 \mathrm{~m}$ \\
& C. Pond Uluklubuk & $995 \mathrm{~m}$ \\
4 & d. Pond Weseben & 1.23 \\
& Mean value of tidal range (h) & 2 times of high tide \\
& Tidal pattern & 2 times of low tide \\
\hline
\end{tabular}

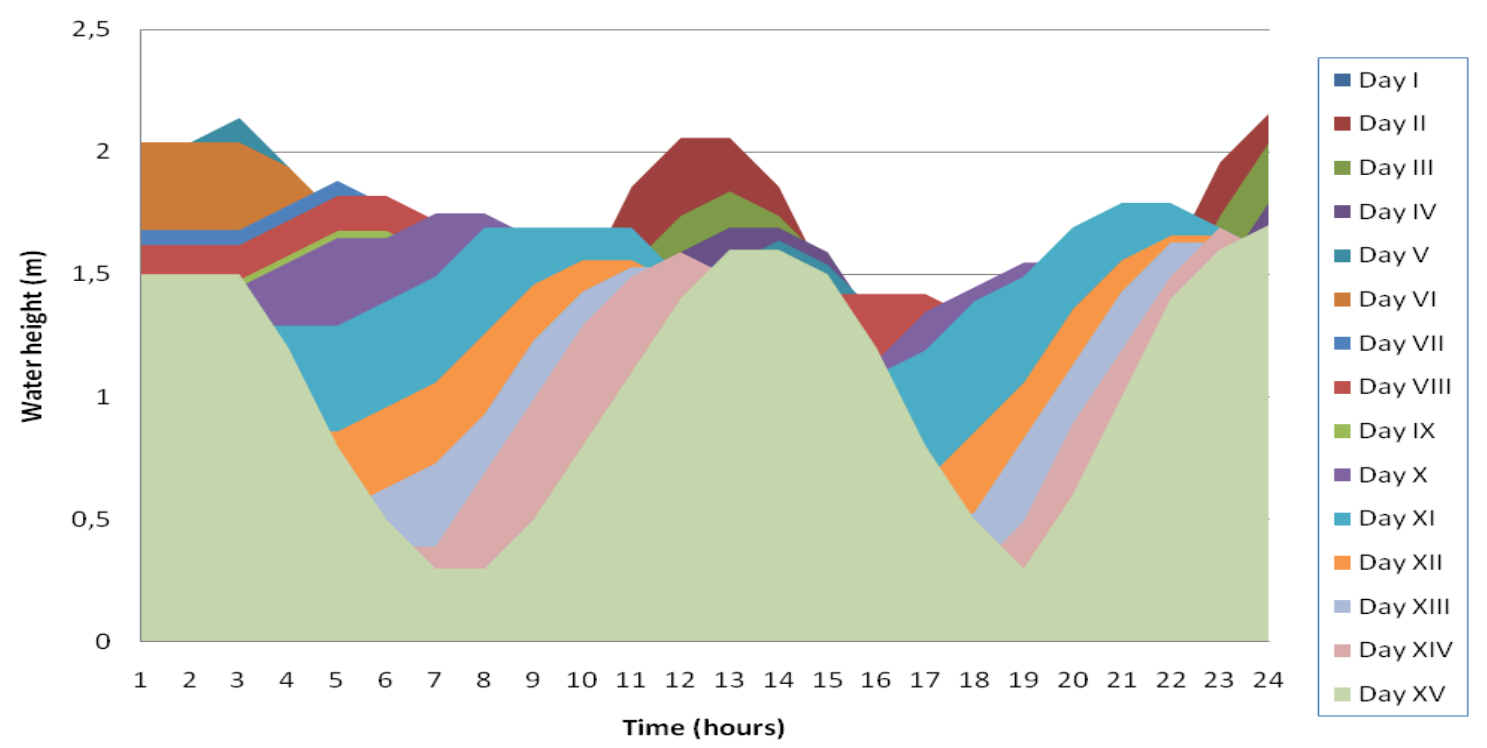

Figure 2 - Tidal changes in the waters of Wewiku District

Observation of tidal water conducted for 15 days is in accordance with Pariwono's [27] claim about a prediction tidal conditions of a waters requires measurement of data for at least 15 days. The tidal type is determined by the frequency of high and low tides every day. If the waters experience two high tides and two low tides in a day as observed and measured by the tide height, the tidal type in Wewiku waters is classified as a semi-diurnal tide type.

The tidal pattern in the coastal areas of Wewiku District can actually result in differences in the volume of the nearshore waters which will give a change to the area of water level. The volume of water in the nearshore of Wewiku District will experience an increase during high tides, hopefully at full moon. Vice versa, the volume of water will decrease on no-moon nights. According to Bishop [28], tidal actions can result in differences in the volume of water and in water level. Pariwono [27] explains that the difference in tide height is also influenced by the location of the waters, in addition to the influence of full moon and half moon (sickle) nights. 
The average tidal range of $1.23 \mathrm{~mW}$ in Wewiku waters is actually a guide in determining the bottom of the pond yard which should not be higher than the Mean Sea Level (MSL), to facilitate filling and drying of pond water especially if the cultivation system is still traditional/traditional plus, which relies on gravity for filling the pond. According to Mustafa and Taranamulia [29], the ideal tidal range for shrimp farming is between $1.5-2.5 \mathrm{~m}$ while Asbar [30] argues that ideal tidal range for traditional pond cultivation is $1.30 \mathrm{~m}$.

Nontji [31] states that in the nearshores, especially in narrow bays or straits, the movement of the waters will cause tidal currents. It is usually alternating, if the water level moves up, the water will flow in. If the water level moves down, then the current flows out. In certain places, this tidal current can be quite strong. Nontji even notes that the tidal potential of seawater currents on the islands of Nusa Tenggara can reach up to $2.5 \mathrm{~m} / \mathrm{sec}$, especially at full moon, whereas it is usually less than $1.5 \mathrm{~m} / \mathrm{sec}$ in other areas, and less than $0.5 \mathrm{~m} / \mathrm{sec}$ in the open sea. The measurement of the velocity of tidal currents at the Wewiku coast indicates that the highest velocity at high tide reaches $1,786 \mathrm{~m} / \mathrm{sec}$ while the velocity at low tide reaches $1.042 \mathrm{~m} / \mathrm{sec}$. This proves Nontji's [31] statement that the velocity of tidal current in NTT as an archipelago is relatively high compared to other regions with a tidal velocity less than $1.5 \mathrm{~m} / \mathrm{sec}$.

Poernomo [25] explains further that the location of ponds for shrimp farming should not be too far from the water sources as shrimp farming activities, especially with traditional and traditional plus cultivation systems, still rely heavily on tides for filling the water into the ponds, which is in contrast to the semi-intensive and intensive technology which use the pump.

Based on the data in Table 1, the distance from the coastline to Weseben station is $0.995 \mathrm{~km}$, to Tuatolu station is $1.720 \mathrm{~km}$, and to Baderai station is $1.8 \mathrm{~km}$. While the furthest location is the Ulukklubuk station, reaching up to $2.818 \mathrm{~km}$ from the coastline. The data indicates that the location of the ponds in each station is still quite far from the required distance according to the traditional plus, semi-intensive and intensive cultivation methods $(130-900 \mathrm{~m})[23,32,25,22,33]$. Water sources that are too far away can impact water quality and quantity negatively, and may compromise productions [25].

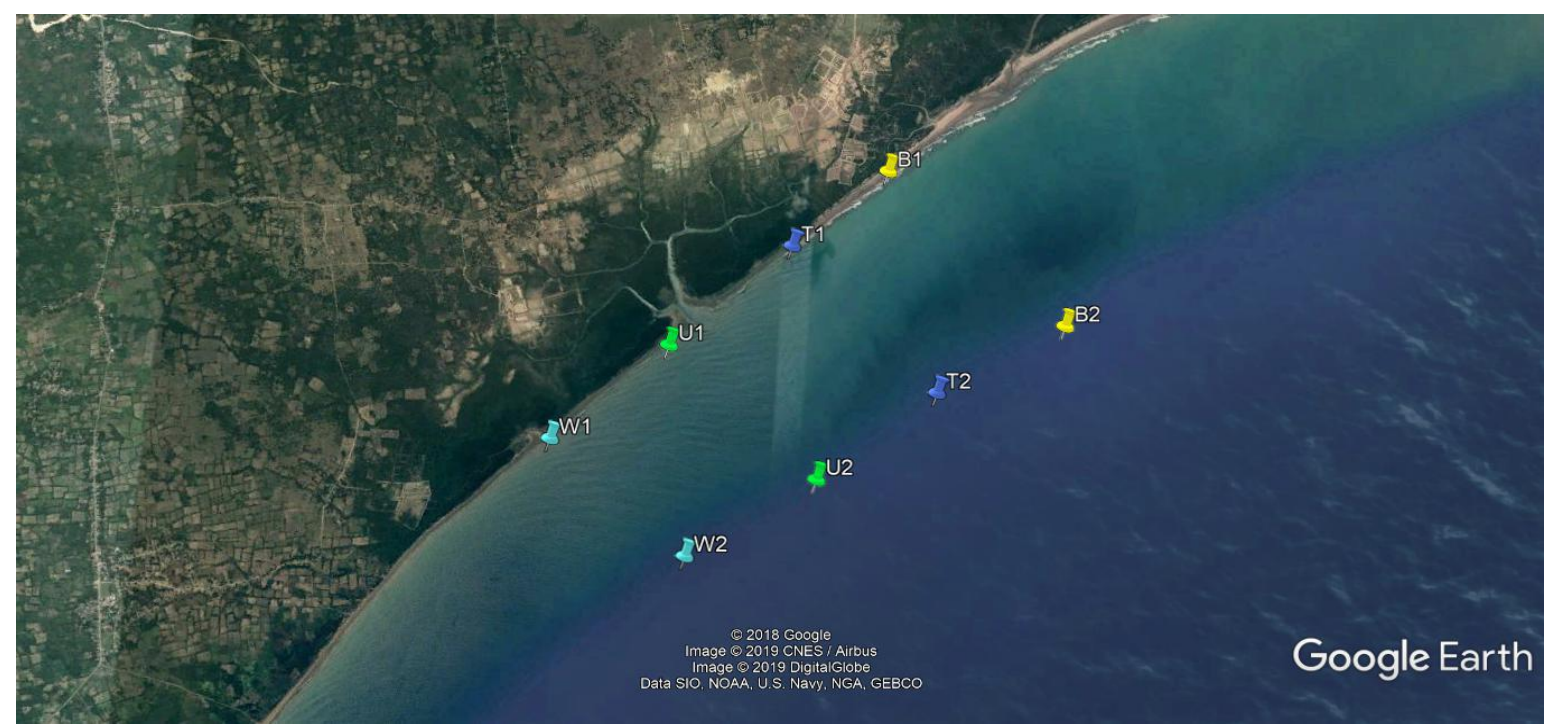

Figure 3 - Coordinates for determining the nearshore bedslope at 4 research stations:

W $(1,2)$ Weseben Coordinates, U $(1,2)$ Uluklubuk Coordinates, T $(1,2)$ Tuatolu Coordinates, $\mathrm{B}(1,2)$ Baderai Coordinates

Additionally, the data in Table 1 shows the coastline length of 3 coastal villages in Wewiku District reaching 5,920 m, starting from Weseben beach at $9^{\circ} 44.668^{\prime} \mathrm{S} 124^{\circ} 50,543^{\prime} \mathrm{T}$ to the coast of Baderai at $9^{\circ} 42.422^{\prime} \mathrm{S} 124^{\circ} 52,866^{\prime} \mathrm{T}$. The length of the coastline determines the distribution of the volume of water entering the coast, especially the pond area when the tides change. The nearshore bedslope of Wewiku is sloping from $3 \%$ to $6 \%$, causing a large 
tidal effect to the coastal area, greater than typically steep bedslopes. This situation is in accordance with the real condition at almost all research stations for even though the distance of the pond area from the shoreline is quite far, the tidal effect of the sea is still significant at a distance of $3 \mathrm{~km}$ from the coastline, passing through existing natural channels. This is in accordance with the statement of Kapetsky et al.'s [32] and Poernomo's [25] that the slope of land for shrimp farming should not be greater than $10 \%$ since it is considered not suitable.

The nearshore bedslope affects the tidal currents entering the coastal area. The average bedslope of the nearshore, as presented in Table 2, shows that the bedslope of Wewiku waters is 0.17710 , obtained from the calculation of the highest and lowest waters contours at each coordinate as shown in Figure 3, accompanied with the data in Table 2. According Bowden [34], currents caused by tides are influenced by the seabed, where the strongest currents will be found near the surface and will decrease in velocity as it approaches the seabed.

Table 2 - The analysis result of the nearshore bedslope of Wewiku District

\begin{tabular}{ccccccc}
\hline Station & \multicolumn{2}{c}{ Measurement Position } & Distance & Slope $(\mathrm{m})$ & Elevation $(\mathrm{m})$ & Degree of Slope $(\mathrm{Tg} \Theta)$ \\
\hline Baderai & 706150 & 8926098 & 1939.14 & 0.002 & 1 & 0.1182 \\
& 707624 & 8924838 & & & -3 & 0.2669 \\
Tuatolu & 705392 & 8925415 & 1698.585 & 0.0047 & 0 & 0.2114 \\
& 706607 & 8924228 & & & -8 & 0.11188 \\
Uluklubuk & 704443 & 8924530 & 1626.11 & 0.00369 & -6 & 1 \\
Weseben & 705677 & 8923471 & & & -2 & 0.177095 \\
\hline
\end{tabular}

Source: Analysis Result.

Note: Distance Estimation Formula $=\sqrt{ }(X 2-X 1) 2+(Y 2-Y 1) 2 ;$ Slope $=($ Elevation I - Elevation II $)$ : Distance; Degree of slope $=\operatorname{tg}^{\wedge}-1 \times$ value of slope.

According to Officer [35], the movement of water masses in coastal areas, apart from being caused by the movement of water masses on the high seas, is affected by tides, while circulation in nearshore waters such as straits, bays and estuaries is strongly affected by tides. In the period between low tide and high tide (ranging from 6-12 hours), the mass of sea water flows from the high seas to the coast, or enters bays/estuaries.

From the discussion above, the physical condition of the tides, the length of the coastline and the bedslope are used to calculate the volume of available water (Vos) in the waters of Wewiku District in one tidal cycle, using the formula by Widigdo and Pariwono [24]. Calculation of the Total Volume of Nearshore of Wewiku District is presented in Table 3.

Table 3 - Calculation of the Total Volume of Nearshore of Wewiku District

\begin{tabular}{cccccc}
\hline Description & \multicolumn{3}{c}{ Station } & \multirow{2}{*}{ Total } \\
\cline { 2 - 5 } & Baderai & Tuatolu & Uluklubuk & Weseben & \\
\hline Length of coastline $(\mathrm{Y} \mathrm{m})$ & 1,200 & 700 & 700 & 3,320 & 5,920 \\
Distance from coastline to farming ponds $(\mathrm{x}) \mathrm{m}$ & 1,800 & 1,720 & 2,818 & 995 & 7,333 \\
Nearshore bedslope $(\mathrm{tg} \Theta)$ & 0.1771 & 0.1771 & 0.1771 & 0.1771 & 0.1771 \\
Tidal range $(\mathrm{h}) \mathrm{m}$ & 1.23 & 1.23 & 1.23 & 1.23 & 1.23 \\
\hline
\end{tabular}

Note:

- $V_{o}\left(\right.$ Water volume at high tide, $\left.\mathrm{m}^{3}\right)=0.5$.h.y $(2 \mathrm{x}-\mathrm{h} / \mathrm{tg} \theta)=53,370,687 \mathrm{~m}^{3}$;

- $\mathrm{V}_{\mathrm{s}}\left(\right.$ Water volume at low tide, $\left.\mathrm{m}^{3}\right)=0.5$.h.y $\{2 \mathrm{x}-(2 \mathrm{~h}-1) / \mathrm{tg} \Theta\}=53,365,958 \mathrm{~m}^{3}$;

- $\quad V_{\text {Os }}\left(\right.$ Water volume available in one tidal cycle, $\left.\mathrm{m}^{3}\right)=0.5$.h.y $\{4 \mathrm{x}-(3 \mathrm{~h}-1) / \mathrm{tg} \Theta\}=106,736,645 \mathrm{~m}^{3}$;

- $V_{\text {tot }}\left(\right.$ Total water volume in a day, $\left.\mathrm{m}^{3}\right)=\mathrm{f} . \mathrm{V}_{\text {os }}=213,473,290 \mathrm{~m}^{3}$;

- $\quad$ WT (retention time $)=\left(\mathrm{V}_{\mathrm{o}}+\mathrm{V}_{\mathrm{s}}\right) / \mathrm{V}_{\mathrm{s}}=2$ hour.

The calculation of the volume of water available in Wewiku waters in one tidal cycle based on data of high tide volume, low tide volume, tidal range, coastline length, distance 
from the coastline to farming pond and the slope of seabed is equal to $106,736,644.9 \mathrm{~m} 3$. Tidal frequency of the nearshore of Wewiku District is 2 times/day, the total volume of water available in nearshore (Vtot) of Wewiku District is $2 \times 106,736,644.9 \mathrm{~m} 3$ or 213,473,289.8 m3.

Calculation of retention time is based on multiplication between the results of the division of the volume of water entering the coast at the time of installation and the volume of remaining water at low tide with the volume of residual water at low tide. The calculation result shows the retention time of the volume of water mass in nearshore per tidal cycle is at 2.0 hours. Because the tidal frequency in the Wewiku District coastal area is 2 times/day, the remaining volume of water mass in the Wewiku nearshore waters is at $2 \times 2.0$ hours or equal to 4.0 hours.

Table 4 - Mean Value of Dissolved Oxygen Content within 15 Research Days

\begin{tabular}{|c|c|c|c|c|}
\hline \multirow{2}{*}{ Duration (Hour) } & \multicolumn{4}{|c|}{ Dissolved Oxygen Content (mg/l) } \\
\hline & Baderai Station & Uluklubuk Station & Tuatolu Station & Weseben Station \\
\hline 6.00 & 6.13 & 6.7 & 5.59 & 6.32 \\
\hline 7.00 & 6.72 & 6.54 & 6.03 & 6.54 \\
\hline 8.00 & 6.43 & 6.23 & 6.22 & 6.25 \\
\hline 9.00 & 6.64 & 6.84 & 6.1 & 6.48 \\
\hline 10.00 & 6.77 & 6.78 & 6.16 & 6.23 \\
\hline 11.00 & 7.5 & 6.78 & 6.61 & 6.73 \\
\hline 12.00 & 7.6 & 6.7 & 4.16 & 6.28 \\
\hline 13.00 & 7.8 & 6.37 & 6.9 & 7.02 \\
\hline 14.00 & 9.37 & 6.72 & 5.28 & 6.47 \\
\hline 15.00 & 7.8 & 6.83 & 6.01 & 6.13 \\
\hline 16.00 & 5.7 & 6.47 & 6.07 & 6.48 \\
\hline 17.00 & 5.6 & 6.36 & 6.23 & 5.48 \\
\hline 18.00 & 8.9 & 6.55 & 6.35 & 6.4 \\
\hline 19.00 & 7.23 & 6.5 & 6.05 & 6.4 \\
\hline 20.00 & 7.46 & 6.43 & 6.54 & 6.4 \\
\hline Mean & 7.18 & 6.59 & 6.02 & 6.374 \\
\hline $\operatorname{Max}$ & 9.37 & 6.84 & 6.9 & 7.02 \\
\hline Min & 5.58 & 6.23 & 4.16 & 5.48 \\
\hline Std. Dev & 1.07 & 0.19 & 0.64 & 0.33 \\
\hline
\end{tabular}

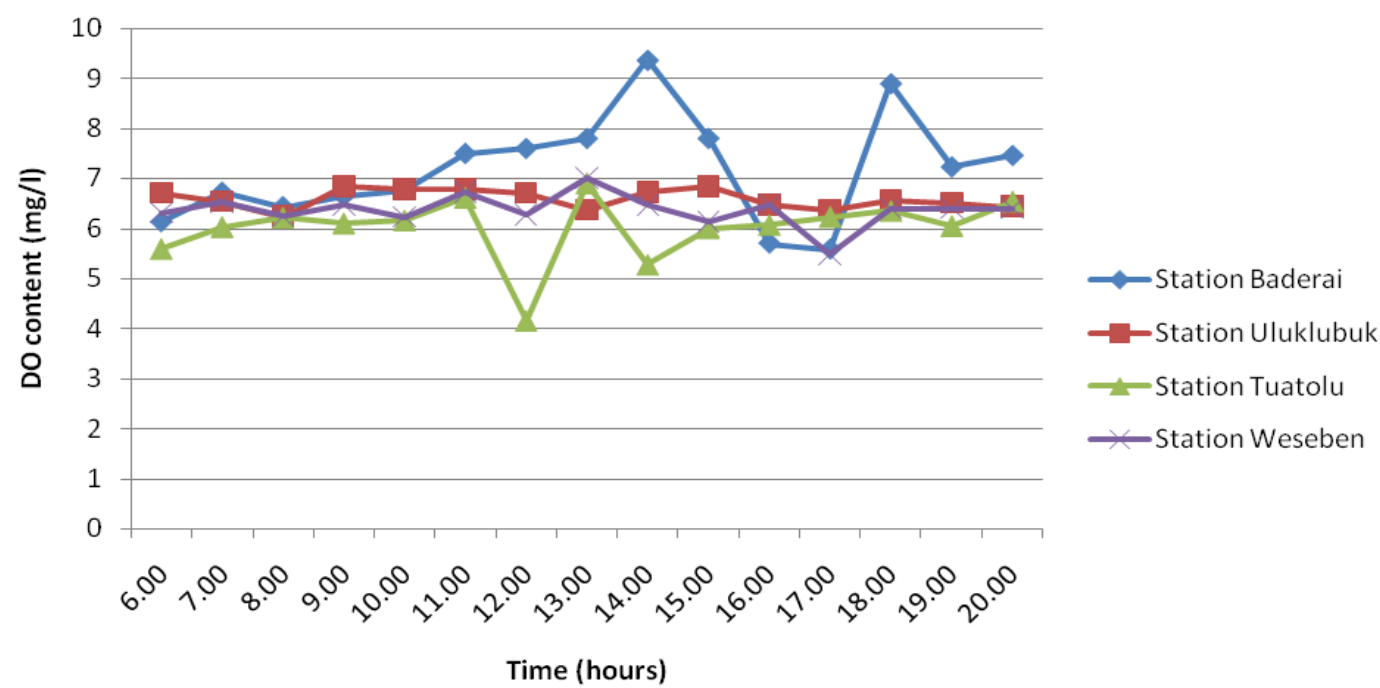

Figure 4 - Dissolved Oxygen (DO) Content at 4 Measured Stations

Estimation of environmental carrying capacity in the nearshore of Wewiku District for developing shrimp farming is done using the approach of environmental carrying capacity based on the available capacity of dissolved oxygen in the water column to decompose the organic waste. The available capacity of dissolved oxygen in the water column is calculated by referring to the modification of the formula proposed by Willoughby referred in Meade [20] and Boyd [21], including the difference between available dissolved oxygen concentration in the water column of nearshore (Oka) and minimum concentration of dissolved oxygen (O2) 
required by cultivated organisms (Obud). The dissolved oxygen content available in the water column due to tides is used to meet the minimum requirements for dissolved oxygen for the cultivation system.

The measurement results for the average dissolved oxygen content of each research station (Baderai, Tuatolu, Uluklubuk, Weseben) for 12 hours in 15 consecutive research days were $7.2 \mathrm{mg} / \mathrm{l}, 6.02 \mathrm{mg} / \mathrm{l}, 6.59 \mathrm{mg} / \mathrm{l}, 6.37 \mathrm{mg} / \mathrm{l}$, with a mean value of dissolved oxygen content of $6.54 \mathrm{mg} / \mathrm{l}$ ( $\mathrm{O}$ water column) as presented in Table 4 and Figure 4.

Lee et al [36] state that the dissolved oxygen content in a waters can be used as an indicator of water quality, and if the dissolved oxygen content of a water is $>6 \mathrm{mg} / \mathrm{l}$, then the waters is classified as uncontaminated or just very lightly polluted. Dahuri et al [37] mention that the concentration and distribution of oxygen in the sea is determined by the solubility of oxygen in water and the biological processes that control the level of consumption and release of oxygen. Physical processes also greatly affect the velocity of oxygen entering and being distributed to the waters. Dissolved oxygen is very important for the life of cultivated organisms for breathing and oxidizing organic matter in farming ponds, and pollution of organic waste can cause a decrease in dissolved oxygen content in waters [38].

Research results by Widigdo [15], Poernomo [25], Boyd [21], Boyd [22], Wedemeyer [26]; Rachmansyah et al. [39] conclude that the minimum level of dissolved oxygen for shrimp farming is $3 \mathrm{mg} / 1$ (Oaq), thus the difference between available dissolved oxygen in the nearshore water column (Oka) and the minimum dissolved oxygen needed by cultivated organisms (Oaq) is $3.54 \mathrm{mg} / \mathrm{l}$. The total volume of water available in nearshore waters (Vtot) of Wewiku District is $213,473,290 \mathrm{~m} 3$.

The volume of water at the highest tide (VPt) is $45,796,100.46 \mathrm{~m} 3$, the volume of water at the lowest tide (VPs) is $6,159,313,122 \mathrm{m3}$, and the daily tidal frequency is 2 times. They all made up the dillution rate (D) of 0.4324 . The flushing time is 2.31 days. The flushing time is calculated using the following formula:

If:

$\mathrm{h}$ (highest tide) $=2.16$

y (coastline length) $=5920 \mathrm{~m}$

$\mathrm{x}$ (distance from coastline to farming ponds) $=3587.5 \mathrm{~m}$

$\mathrm{h}$ (lowest tide) $=0.29$

$\operatorname{tg} \Theta=0.1771$

VPt (Water vol. at highest tide $)=0.5 \times \mathrm{h} \times \mathrm{y}(2 \mathrm{x}-\mathrm{h} / \mathrm{tg} \Theta)=45796100.46$

VPs (Water vol. at lowest tide) $=0.5 \times \mathrm{h} \times$ y $(2 \times-2 \mathrm{~h}-1 / \mathrm{tg} \Theta)=6159313.112$

Dillution Rate $(D)=$ [Vhighest tide-Vlowest tide]: $f$ * $V p t=0.432752865$

Flushing time (day) $=1 / \mathrm{D}=2.31$ day

The total volume of Wewiku nearshore waters is $213,473,289.8 \mathrm{~m} 3$, so the total capacity of available dissolved oxygen (O2) in nearshore waters can be calculated by multiplying the total volume of seawater in Wewiku nearshore waters with flushing time. The minimum dissolved oxygen level needed by cultivated organisms, or in this case the total capacity of available dissolved oxygen (O2) in nearshore waters is equal to (213.473.290 $\mathrm{m} 3 / 2.31) \times 3.54 \mathrm{mg} / \mathrm{l}=327,140.89 \mathrm{~kg} \mathrm{O} /$ day.

According to Willioghby as referred in Meade [20], the volume of dissolved oxygen needed to decompose organic waste that enters and resides in nearshore waters is $0.2 \mathrm{~kg}$ $\mathrm{O} 2 / \mathrm{kg}$ of organic waste. Thus, if the available capacity of oxygen in Wewiku waters is $327,140.89 \mathrm{~kg} \mathrm{O} 2 /$ day, the volume of organic waste that can be contained by Wewiku waters without exceeding the environmental carrying capacity is $327,140.89 \mathrm{~kg} / \mathrm{O} 2: 0.2 \mathrm{~kg} / \mathrm{O} 2 \mathrm{per} \mathrm{kg}$ of waste $=1,635,704.43 \mathrm{~kg}$ organic waste/day. In other words, the volume of organic waste that can be contained by nearshore waters of Wewiku District without exceeding the environmental carrying capacity is $1,635,704.43 \mathrm{~kg} /$ day. Racocy and Alison in Widigdo and Pariwono [24] stated that in order to free the waters from pollution, the quantity of seawater taking the waste must at least be 100 times the quantity of waste disposed.

After observing that the quantity of seawater entering Wewiku nearshore waters is $213,473,290 \mathrm{~m} 3$ and the volume of organic waste that can be contained by nearshore waters is $1,635,704.43 \mathrm{~kg} /$ day, it can be concluded that the Wewiku waters are able to contain, 
dilute, and assimilate all incoming waste and does not cause harmful effects. Waste entering nearshore and marine waters will interact with sea water and produce typical waste characteristics that can evaporate, dissolve and be dispersed [40].

Quantification of waste loads resulted from shrimp farming is usually only carried out on intensive, semi-intensive and traditional plus technologies as in these, the shrimp maintenance relies on artificial food (pellets), while the traditional one relies on natural food. Artificial food has been named the culprit for the decline in the quality of the aquatic environment for the shrimps do not always eat all of it, and then the remaining pieces will turn into organic waste and becomes the cause for decreased environmental quality [41, 42].

Referring the results of Allaudin's study [23] on the application of intensive shrimp farming technology with a population density of 126 shrimps $/ \mathrm{m} 2$ and 50 shrimps $/ \mathrm{m} 2$, respectively, which produce organic waste in the form of Total Suspended Solid (TSS) of $9,288.52 \mathrm{~kg} / \mathrm{ha} /$ farming season and 2,387.46 kg/ha/farming season, while semi-intensive and traditional plus farming technologies produce $1,155.29 \mathrm{~kg} / \mathrm{ha} /$ farming season and 487.90 $\mathrm{kg} / \mathrm{ha} /$ farming season, respectively.

The volume of organic waste from shrimp farming in the form of TSS will be disposed to the nearshore waters and will potentially pollute it. Daily TSS concentration in nearshore waters depend heavily on the total volume of water containing the waste (Vtot), the volume of discarded shrimp pond waste, tidal patterns and flushing time [43].

Still referring to Allaudin's [23] study on the volume of organic waste produced at various shrimp farming systems, and taking into account the calculation of the volume of organic waste that can be contained by Wewiku District's nearshore waters without exceeding the environmental carrying capacity, the result of calculation of land area and pond production according to the environmental carrying capacity is presented in Table 5.

Table 5 - Capacity to contain waste, pond area and production carrying capacity

\begin{tabular}{|c|c|c|c|c|}
\hline $\begin{array}{l}\text { Shrimp Farming } \\
\text { Technology }\end{array}$ & $\begin{array}{l}\text { Volume of organic waste } \\
\text { disposal }(\mathrm{kg} / \mathrm{ha} / \mathrm{MT})^{(\mathrm{a})}\end{array}$ & $\begin{array}{l}\text { Capacity to contain } \\
\text { organic waste } \\
(\mathrm{kg} / \mathrm{day})^{(\mathbf{b})}\end{array}$ & $\begin{array}{l}\text { Pond area in accordance } \\
\text { with carrying capacity } \\
\text { (ha) })^{(\mathrm{c})}\end{array}$ & $\begin{array}{l}\text { Production carrying } \\
\text { capacity (tons/ MT) } \text { (d) }^{\text {(d) }}\end{array}$ \\
\hline $\begin{array}{l}\text { Intensive (126 } \\
\left.\text { fish } / \mathrm{m}^{2}\right)\end{array}$ & $9,228.52$ & $1,635,704.43$ & 177.24 & $3,240.03$ \\
\hline $\begin{array}{l}\text { Intensive }(50 \\
\left.\text { fish } / \mathrm{m}^{2}\right)\end{array}$ & $2,387.46$ & $1,635,704.43$ & 685.12 & $4,028.52$ \\
\hline $\begin{array}{l}\text { Semi intensive } \\
\left(25 \mathrm{fish} / \mathrm{m}^{2}\right)\end{array}$ & $1,155.29$ & $1,635,704.43$ & $1,415.84$ & $4,516.54$ \\
\hline $\begin{array}{l}\text { Traditional plus } \\
\left(8 \mathrm{fish} / \mathrm{m}^{2}\right)\end{array}$ & 487.90 & $1,635,704.43$ & $3,352.54$ & $2,581.46$ \\
\hline
\end{tabular}

Note: $a=$ The volume of organic waste discharges according to the research by Allaudin (2010); $b=$ The result of the calculation of the capacity to contain organic waste in the Wewiku nearshore waters; $c=b: a ; d=c$ x each production scale (intensive with a population density of 126 shrimps $/ \mathrm{m}^{2}$, producing 18.28 tons $/ \mathrm{ha} / \mathrm{MT}$; intensive with a population density of $50 \mathrm{shrimps} / \mathrm{m}^{2}$, producing 5.88 tons/ha/MT; semi-intensive with a population density of $25 \mathrm{shrimps} / \mathrm{m}^{2}$, producing 3,20 tons/ha/MT; traditional plus with a population density of 8 shrimps $/ \mathrm{m}^{2}$, producing 0,777 tons $/ \mathrm{ha} / \mathrm{MT} ; \mathrm{MT}=$ Farming Season.

Table 5 shows that based on capacity to contain organic waste and oxygen available capacity in the waters, the area that can be developed intensively for farming ponds without exceeding the environmental carrying capacity is 177.24 ha (population density of 126 shrimps/m2), producing 3,240.03 tons/MT and 685.12 ha (population density of 50 shrimps/m2) with production capacity reaching $4,028.52$ tons/MT. While the land area that is in accordance with the environmental carrying capacity for semi-intensive and traditional plus farming are 1,415.84 ha and 3,352.54 ha, respectively, with production capacity of $4,516.54$ tons/MT and 2,581.46 tons/MT, respectively.

\section{DISCUSSION OF RESULTS}

The results of the calculation of pond production based on the carrying capacity of the Wewiku waters above are only based on the calculation of shrimp production based on the area of cultivation. Potentials for shrimp production in the area of cultivated land will certainly depend on the choice of the type of shrimp and the farming system that will be developed. 
According to Farkan et al [44], with intensive cultivation systems, tiger shrimp production can reach up to 12 tons/year while vanamme shrimp can reach up to 24 tons/ha/year. Thus, based on environmental carrying capacity, average shrimp production according to Farkan et al [44] may reach an average of 18 tons/ha/year. The result of the Allaudin's [23] study also shows that with a population density of 126 shrimps $/ \mathrm{m} 2$, the average production of shrimp could reach 18.28 tons/ha/year, and the production would only reach 5.88 tons/ha/year for a population density of 50 shrimps/m2. In a semi-intensive farming system, Farkan et al [44] mentions that tiger shrimp production could reach 5.1 tons/ha/year, while vanname shrimp may reach 12 tons/ha/year, although Allaudin [23] also suggests shrimp productions of 3.20 tons/ha/year and 0.77 tons/ha/farming season in a traditional plus farming system.

The real condition on field and various references above suggest that efforts to develop aquaculture activities in Wewiku District, Malaka Regency with a choice of shrimp farming can be done by considering the land area and choice of cultivation systems for productions that do not exceed the environmental carrying capacity of Wewiku waters. Farkan et al [44] states that the traditional and extensive technology has a more sustainable effect than the intensive technology, but the demand for shrimp food is a burden for increasing production, and one of the efforts to increase carrying capacity is to increase the availability of seawater and the number of bacteria that eat organic waste. Meanwhile, according to Edward [45], efforts to increase the carrying capacity of the water resources can be done by combining modern and traditional cultivation technologies, best management practices, appropriate location selection, focusing land and aquatic environmental carrying capacity, and efficiency of land and water utilization.

Ting et al [46] explains other factors that affect aquaculture productivity, including environmental, social, institutional and economic factors. According to Sa et al [47], land management and management of shrimp farming really affect farming productivity. Ahmad [48], McDowell and Hess [49], Schmitt and Brugere [50], Suwarsih et all., [51], argue that increasing the carrying capacity of the aquatic environment can be done by considering land management policies, farming technology and ecological and social support. Thus, the ecofriendly shrimp farming can be developed in the Wewiku District of Malaka Regency by considering shrimp production in land area that is in accordance with the carrying capacity of the nearshore waters to dilute organic waste produced from shrimp farming.

\section{CONCLUSION}

Based on the carrying capacity of the aquatic environment on the nearshore of Wewiku District, the area of land that can be developed for shrimp farming ponds with intensive farming pattern is 177.24 ha (126 shrimps/m2) with a production capacity of $3,240.03$ tons/MT. For a land area of 685.12 ha (population density of 50 shrimps $/ \mathrm{m} 2$ ), shrimp production capacity reaches $4,028.52$ tons/MT. In semi-intensive and traditional plus cultivation systems, land area suitable for environmental carrying capacity is 1,415.84 ha and $3,352.54$ ha with production capacity of 4,516.54 tons/MT and 2,581.46 tons/MT, respectively.

\section{REFERENCES}

1. Liufeto, F., Nuddin Harahab., Arning Wilujeng.,Soemarno, 2018. Market Demand Analysis of Prawn and Milkfish for Cultivation Business Development in malaka Regency, West Timor Indonesia. International Journal of Business Mareting and Management (IJBMM). Volume 3. P.P 34-45

2. BPP (Badan Pengelola Perbatasan) NTT, 2011. Laporan Kajian Potensi and Tata Ruang Kawasan Perbatasan di Kabupaten Belu. Laporan Penelitian Kerjasasama Lembaga Pemberdayaan and Pengembangan Wilayah Kupang

3. ATSEF (Arafura and Timor Sea Expert Forum), 2006. Potret Sumberdaya Kawasan Laut Arafura and Laut Timor. Kerjasama ATSEF dengan BRKP, Jakarta. 
4. BKIPM (Balai Karantina Ikan Pengendali Mutu and Keamanan Hasil Perikanan) , 20102014. Data arus lintas hasil perikanan di perbatasan Motaain. Tidak dipublikasi.

5. BPS (Badan Pusat Statistik) Kabupaten Belu, 2008-2014. Produksi Perikanan: Kabupaten Belu Dalam Angka. Pemerintah Kabupaten Belu

6. Belton, B and Thilsted, S.H., 2014. Fisheries in transition: food and nutrition security implications for the global South. Global Food Security, 3(1),59-66

7. FAO, 2012. The state of world fisheries and aquaculture 2012. Rome: Fisheries and Aquaculture Development, Food and Agriculture Organization of the United Nation.

8. FAO, 2006a. FishStat. Fisheries Departement, Food and Agriculture Organization of the United Nation. Rome Italy

9. FAO, 2006b. Production: Environment, species, quatities and values. Chapter 2 in Expert Workshop on Global Review on Status and Trens in Aquaculture and Prospective analysys of Future Aquaculture Development. Guangzhou City, Guangdong, China.12-15 March 2006. Food and Agriculture Organization of the United Nations, Rome Italy

10. FAO, 2004. The State of world Fisheries and Aquaculture 2004. Fisheries Departement, Food and Agriculture Organization of the United Nations. Rome Italy

11. Barbier, E.B and Cox,M. 2002. Economic and demography factors affecting mangrove lloss in the coastal provinces of Thailand, 1979-1996. Ambio, 31, 351-357.

12. Tacon, AGJ. 2001. Increasing the Contribution od Aquaculture for Food Security and Poverty Alleviation . In A Tacon (ed) Aquaculture in third millennium. Bangkok, Thailand, 20-25 Februari 2000. NACA, FAO, Rome pp 66-71

13. Leung., P.S., C.S. Lee and P.J. O'Bryen., 2007. Species and system selection for sustainable aquaculture.Blackwell publishing, IOWA-USA.

14. Anderson 2007. Sustainable aquaculture: what does it mean and How do we get there ? In Leung et al.,.., 2007. Species and system selection for sustainable aquaculture, Blacwell Publishing IOWA USA Anderson

15. Widigdo, B., 2002. Perkembangan and peranan perikanan budidaya dalam pembagunan. Makalah disampaikan dalam seminar penetapan standar kualitas air buangan tambak. Ditjen Perikanan Budidaya, Puncak 7-9 Agustus 2002.

16. Lewis, R.R., Philip M.J., Macintosh, D.J., 2003. Thematic review on coastal wetland habitats and shrimp aquaculture. Report prepared under the world bank, NACA, WWF and FAO Consorsium Program on Shrimp Farming and Environment. Work in Progress for Public Discussion. Published by the consorsium.

17. Nash, C., 1995. Aquaculture Sector Planning and management. The University Press, Cambridge.

18. Johsen RI, Grahl-Nielson O, Lunestad BT. 1993. Environmental distribution on Organic waste from marine fish farm. Aquaculture, 118:229-224

19. Soewardi K. 2002. Pengelolaan kualitas air tambak. Makalah dalam seminat penetapan standar kualitas air buangan tambak. Ditjen Perikanan Budidaya, 7-9 Agustus 2002

20. Meade, J. W. 1989. Aquaculture Management. AnAvi Book, Van Nostrand Reinhold. New York. 175p.

21. Boyd CE., 1990. Water quality in ponds for aquaculture. Alabama Agricultural Experiment Station. Auburn University, Alabama, 482p

22. Boyd, C.E., 1999. Management of Shrimp pond to reduce the eutrhrophication potensial of effluents. The Advicae, December 1999:12-14

23. Alauddin, M.H.R., 2010. Optimasi Pemanfaatan Wilayah Pesisir Berbasis Daya Dukung Bagi Pengembangan Budidaya Tambak Udang di Kecamatan Mangara Bombang,Kabupaten Takalar Provinsi Sulawesi Selatan. Disertasi. Sekolah Pasca Sarjana IPB.

24. Widigdo B, and Pariwono. 2003. Daya dukung pantai utara Jawa Barat untuk Budidaya udang (studi kasus di kabupaten Subang, Teluk Jakarta and Serang). Jurnal IImu IImu Perairan and Perikanan Indonesia 1, 10-17

25. Poernomo, A., 1992. Pemilihan Lokasi Tambak Udang berwawasan Lingkungan. Pusat penelitian and pengembangan perikanan - Badan Penelitian and Pengembangan Pertanian-Departemen Pertanian, Jakarta. 
26. Wedemeyer GA.1996. Physiology of fish in intensive cultures system. Chapman and Hall.New York. $232 \mathrm{p}$

27. Pariwono, J.I. 1985. Tides and Tidal Phenomenon in Asean Region. Australian Cooperative Programmes in Marine Sciences. Prelim.Rep.FIAM, South Australia

28. Bishop JM. 1984. Applied Oceanography. John Wiley and Sons, Inc. Newyork: 252 p

29. Mustafa A, Taranamulia. 2008. Model analisis spasial kesesuain lahan tambak skala semi detail berdasarkan peubah kunci tambak sistem ekstensif and semi intensif. Balai Riset Perikanan Budidaya Air Payau Maros. 14 hal.

30. Asbar 2005. Optimalisasi pemanfaatan kawasan pesisir untuk pengembangan budidaya tambak berkelanjutan di kabupaten Sinjai Sulawesi Selatan. Disertasi program Doktor Sekolah Pasca Sarjana IPB (tidak dipublikasikan)

31. Nontji, A. 1987. Laut Nusantara. Penerbit Djambatan, Jakarta

32. Kapestky, J.M., L. Mc Gregor, and H. Nanne. 1987. A Geographical kinformation System and Satellite Remote Sensing to Plan for Aquaculture Development: A FAO UNEP/GRID Cooperative Study in Costa Rica. FAO Fish. Tech. Pap. (287): 51.

33. Prasita, 2007. Analisis daya dukung lingkungan and optimalisasi pemanfaatan wilayah pesisir untuk pertambakan di kabupaten Gresik. Disertasi. Program Studi Pengelolaan Sumberdaya Pesisir and Lautan. Sekolah Pasca Sarjana Institut Pertanian Bogor. 145 hal.

34. Bowden,K,F., 1983. Physical Oceanography of Coastal Waters. Ellis Horwood Limv.

35. Officer, C.B 1976. Physical Oceanography pf Estuaries (and Associated Coastal Waters). John Wiley \& Sons

36. Lee., C. D, S.B Wang and Kuo. 1978. Bentic macro invertebrate and fish as biology indicators of water quality, with reference to community diversity index. International Conference of water Pollutan Control In Developing Countries. Bangkok Thailand

37. Dahuri, R., J. Rais, Sapta P. Ginting., Sitepu., 2001. Pengelolaan Sumber Daya Pesisir and Lautan Secara Terpadu. Pradya Paramita, Jakarta 326 pp.

38. Efendi H. 2003, Telaah kualitas air bagi pengelolaan sumberdaya and lingkungan perairan. MSP-IPB Bogor

39. Rachmansyah, Makmur, Undu MC. 2008. Peningkatan kualitas lingkungan tambak dengan penerapan probion pada budidaya udang. Laporan Kegiatan Balai Besar Pengembangan Budidaya Air Payau Jepara. Tahun 2008. Hal: 193-208

40. Mukhtasor, 2007. Pencemaran Pesisir and Laut. Cetakan Pertama. PT Pradnya Paramita, Jakarta, 322 hal.

41. Mc Donald, Tikkanen ME, Axler CA, Larsen RP, CP and Host G, 1996. Fish simulation culture model (FIS-C): a bioenergetics based model for aquaculture wasteload application. Aquaculture engineering, 15 (4): 243-259

42. Horowitz A, Horowitz S. 2000. Microorganism and feed management in aquaculture. Global Aquaculture Alliance, The Advocate, Vol 3, Issue 2 April 2000, p:33-34

43. Barg, U. C. 1992. Guideliness of The Promotion of Environmental Management of Coastal Aquaculture Development. Fisheries Technical Paper 328, FAO, Rome. 122p.

44. Farkan, M., D. Djokosetiyanto, R.S Widjaja, Kholil, Widiatmaka., 2016. Carrying capacity analysis of area of sustainable Shrimp Cultivation Based on Land Suitability and water availability in coasta; Bay of Banten Indonesia. International Journal for research in Biology and Pharmacy. Volume 2 p:29-40

45. Edward, P., 2015. Aquaculture Environment Interactions: Past, Present and Likely Future Trends. Aquaculture (2015) doi: 10.116/j.aquaculture.2015.02.001.1-11

46. Ting $\mathrm{KH}$, Lin HT, Jhan HT, Huang TJ, Wang CM, Liu WH, 2015. Applicaion ps Sustainable Fisheries Development Indicator System For Taiwan Aquaculture Industry. Elsivier Aquaculture 437 (2015). Doi: 10.1016.398-407

47. Sa TD, de Sousa RR, Rocha IRCB, de Lima GC, Costa FHF, 2013. Brackish Shrimp Farming In Northestern Brazil: The Environment and Socio - Economic Impacts and Sustainability. Natural Resources Journals, 2013, 4,538-550. 
48. Ahmad T., 2006. Perikanan budidaya sebagai langkah maju pemanfaatan terkendali sumberdaya perikanan. Jakarta: Badan Riset Kelautan and Perikanan, Departemen Kelautan and Perikanan.

49. McDowell, JZ and J.J Hess 2012.Multiple Stress on livelihoods in teh Bolivian Highlands Under Changing Climate. Journal Global Environment Change Journal home page: www. Elsevier.com/locate/gloenvcha USA 22, p.342-352

50. Schmitt LHM, Brugere C. 2013. Capturing ecosystem services, stakeholders preferences and trade - Offs in Coastal Aquaculture Decisions: A Bayesian Belief Network Application. PloS One 8 (10): 275956. DOI: 10.1371, 1-16 p

51. Suwarsih, Marsoedi, Nuddin Harahab and Mohammad Mahmudi, 2016. The Utilization Analysis Coastal District Of Jenu Tuban As Land Vannamei Shrimp With Geographic Information System (Gis), Asian Journal of Microbiology, Biotechnology and Environmental Sciences. Vol. 18, No. (2): 2016: 379-389; http://www.envirobiotechjournals.com/ 